\title{
Analyses and findings of unusual substitute materials in a raincoat from WWII
}

\author{
Clara Bratt Lauridsen ${ }^{1 *} \mathbb{B}$, Theis Brock-Nannestad ${ }^{2}$ and Kim Pilkjær Simonsen ${ }^{1}$
}

\begin{abstract}
Due to the coating materials used, historic raincoats are vulnerable to degradation and rarely survive long periods of time. The investigated raincoat dating from 1943 is no exception - the coating is unusually stiff and flaking off in areas around folds and cracks. Study into its material composition can contribute to important knowledge of the availability of materials for waterproof clothing during the time of the German occupation of Denmark (1940-1945) when the usual materials for raincoats, cotton fabric and rubber, were in short supply. Optical microscopy and attenuated total reflectance-Fourier transform infrared spectroscopy (ATR-FTIR) identified the fabric to consist of rayon staple fibres and paper yarn, and the coating to be based on cellulose nitrate (CN) lacquer and an unknown plasticiser. Though the results are atypical for a raincoat, they are in good accordance with the raw materials available in Denmark in 1943. Analysis by matrix-assisted laser desorption-ionisation mass spectrometry (MALDI-MS), and ${ }^{1} \mathrm{H}$ and ${ }^{13} \mathrm{C}$ nuclear magnetic resonance spectroscopy (NMR), identified the plasticiser as poly(1,3-butylene) adipate. Powder X-ray diffraction (PXRD) moreover identified the pigment as titanium white of the anatase form. By historical discussion, this study argues that IG Farben is the likely producer of poly(1,3-butylene) adipate, even though the first known marketing of the plasticiser is from 1986 where the Swiss firm Ciba-Geigy introduced poly(1,3-butylene) adipate as a plasticiser for PVC cling films under the tradename Reoplex ${ }^{\circledR} 346$. The results give an interesting insight into the use of substitution products during WWII and provide new information on polymer science of the time.
\end{abstract}

Keywords: Rayon staple fibres, Paper yarn, Cellulose nitrate lacquer, Poly(1,3-butylene) adipate, Buna, IG Farben

\section{Introduction}

When Denmark was occupied by Germany on 9 April 1940 , the country was immediately cut off from other countries that traditionally had supplied a great deal of raw materials. Denmark became dependent on trade that in many ways, was adapted to the German needs [1]. During the five-year period of the German occupation, many substitute products were traded, which had not been traded before and did not continue to be traded after WWII when raw materials were available again. Many of these substitute products were experimental and often created to fulfil immediate needs. Many of them were made with relatively short-lived materials,

\footnotetext{
*Correspondence: cbl@konsvejle.dk

${ }^{1}$ Conservation Centre Vejle, Maribovej 10, 7100 Vejle, Denmark

Full list of author information is available at the end of the article
}

or materials that were not made for the task in the first place. As such, items which have managed to survive until today are typically in a poor condition. However, they should be considered an important testimony of that time and give a first-hand insight in the creative handling of the scarce resources available. A woman's fashion raincoat from Glud Museum, Denmark, dating from 1943 is no exception (Fig. 1). The raincoat, about $100 \mathrm{~cm}$ long, is made of a rather coarse and relative open fabric and the weave can be seen clearly through the light, beige coloured coating (Fig. 1a). The raincoat has a dog collar, snap fasteners made of metal, a belt and metal eyelets under the armpits to allow for ventilation. Inside, the raincoat is provided with the number " 100 " and a trademark that is smeared and barely readable (Fig. 1b). Today the raincoat is unusually stiff, and the coating is flaking off around areas of folds and cracks.

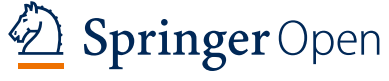

(c) The Author(s) 2021. Open Access This article is licensed under a Creative Commons Attribution 4.0 International License, which permits use, sharing, adaptation, distribution and reproduction in any medium or format, as long as you give appropriate credit to the original author(s) and the source, provide a link to the Creative Commons licence, and indicate if changes were made. The images or other third party material in this article are included in the article's Creative Commons licence, unless indicated otherwise in a credit line to the material. If material is not included in the article's Creative Commons licence and your intended use is not permitted by statutory regulation or exceeds the permitted use, you will need to obtain permission directly from the copyright holder. To view a copy of this licence, visit http://creativecommons.org/licenses/by/4.0/. The Creative Commons Public Domain Dedication waiver (http://creativeco mmons.org/publicdomain/zero/1.0/) applies to the data made available in this article, unless otherwise stated in a credit line to the data. 

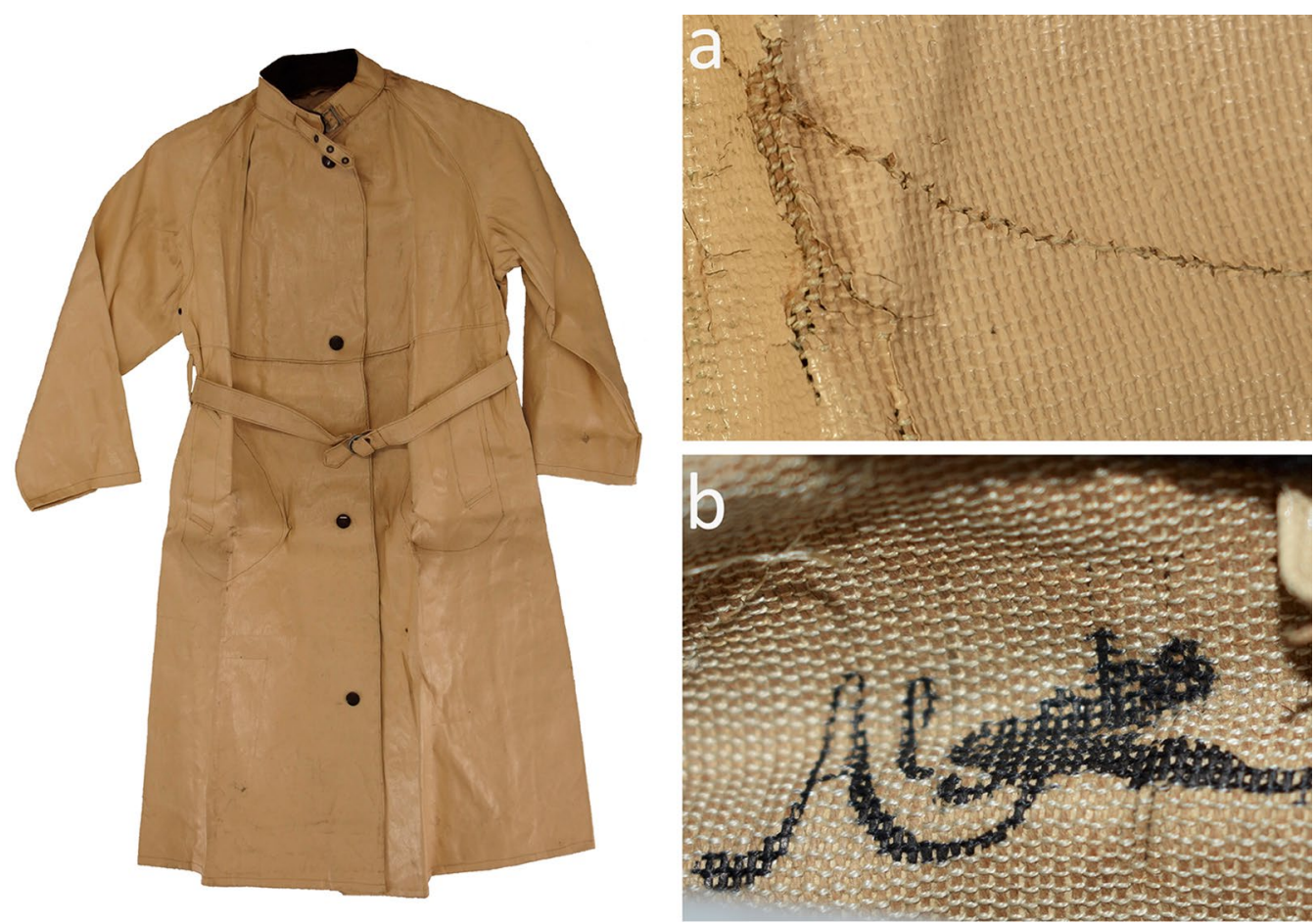

Fig. 1 The raincoat from Al Hansen and details of $\mathbf{a}$ the coating by the non-sealed seam of the pocket and $\mathbf{b}$ the fabric by the smeared trademark showing the white warp and the brown weft

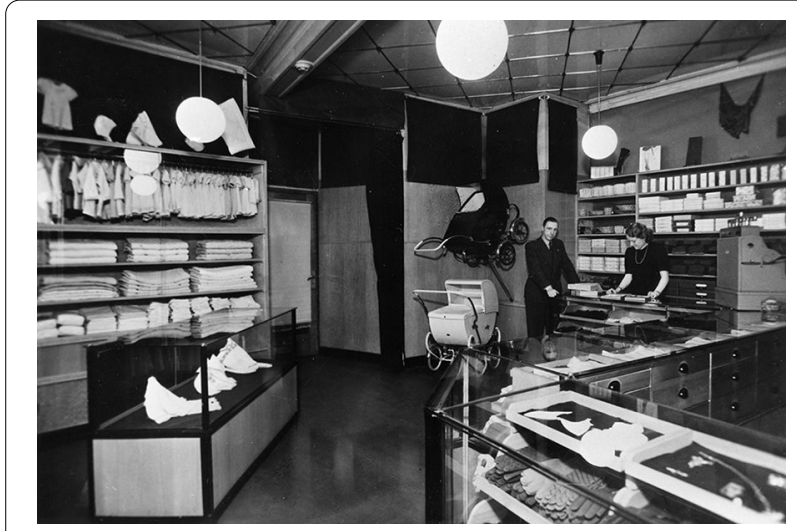

Fig. 2 Interior view of the clothing store Al Hansen, 1943. Photographer unknown. Photo: Vejle City Archives

The raincoat was originally purchased by the clothing store AI Hansen in Vejle, probably with the intention of resale. AI Hansen sold mainly knitwear and yarns but during the occupation, other products were sold as well, in order to fill the shelves (Fig. 2). However, the raincoat was never sold, but stored in the loft of the store until it was given to the open-air Museum in Glud in 1989. The grandchild of the founder of AI Hansen, Anders Jørgen Hygebjerg-Hansen, who took over the store in 1966, mentions the raincoat in his memories: "Then comes WWII with a shortage of goods (...) A raincoat made of paper yarn, which was lacquered to become waterproof, did we keep for long in memory of that time. Now it is at Glud Museum" [2].

As the quote from Hygebjerg-Hansen suggests, being able to provide women's fashion rainwear during the occupation must have been a challenge. Up until the occupation, the most popular women's rainwear in Denmark was rubber coats. Other kinds of rainwear such as impregnated coats and oil skins, were mainly for men's rainwear and workwear [3]. Rubber was in scarce supply and reserved mainly for the tires and tubes of bicycles $[1,4]$. Moreover, during the occupation, Denmark was cut off from the most important fibre for textile, cotton [1].

Using various state-of-the-art analytical techniques, this study investigated the raw materials of the raincoat and looked at their availability in Denmark during the occupation period. Of all clothing, raincoats are some of the most vulnerable and complex, due in particular to the coating materials, which are often prone to degradation [5]. Probably not many raincoats from the war period have survived to our days. However, they constitute an interesting study on the availability of materials and the creativity of the textile industry in a time of restrictions. 


\section{Experimental Samples}

Two samples were taken from the raincoat. Sample 1 of approximately $2 \times 3 \mathrm{~mm}$ was carefully cut from the lifting coating using a scalpel and tweezers ( $c f$. Additional file 1: Fig. S1). This sample allowed FTIR-ATR analysis on the part of the coating turning towards the fabric, that may differ in composition from the topside of the coating.

Sample 2 (approximately $6 \times 10 \mathrm{~mm}$ ) was cut out from a seam allowance with scissors. The seam allowance included the selvedge of the fabric in plain weave ( $c f$. Additional file 1: Fig. S2). The selvedge is reinforced by a double thread in the warp direction and differ from the main fabric, where the warp is single (Figs. $1 \mathrm{~b}$ and 3 ).

\section{Chemicals}

All solvents, including $\mathrm{CDCl}_{3}$, were obtained from Sigma-Aldrich Denmark A/S and used as received.

\section{Extraction and separation}

Sample 1, comprising only the coating, was analysed on both sides with ATR-FTIR without further treatment. Sample 2 underwent further chemical treatment to separate and analyse its different components, based on the FTIR results of sample 1 . The analytical results of sample 1 showed the presence of a cellulose nitrate $(\mathrm{CN})$ based coating and an unknown plasticiser (see results section below). Different from most other organic materials, $\mathrm{CN}$ is insoluble in chloroform, and this was exploited to extract the plasticiser from the coating. Sample 2 was placed in a $5 \mathrm{ml}$ glass vial and just enough chloroform was added to cover the sample.
The next day the sample was taken out, and the chloroform allowed to evaporate at ambient temperature in a fume hood. The extracted plasticiser left over after evaporation consisted of a clear fluid. The loss of plasticiser was observed in the sample by cracking and shrinking of the $\mathrm{CN}$-coating ( $c f$. Additional file 1: Fig. S3). The remaining $\mathrm{CN}$ coating was still adhering firmly to the fabric after the extraction of the plasticiser. To remove the $\mathrm{CN}$ coating from the fabric, the sample was placed in a glass vial and covered with ethyl acetate that readily dissolved the $\mathrm{CN}$ coating. By repeating the procedure, the fabric was washed free of the coating. The first washing, that contained the highest concentration of coating material, was centrifuged for a few minutes to separate the pigment from the solution. The solution was removed to a watch glass with a glass pipette, and the liquid left to evaporate in a fume hood at ambient temperature. After evaporation, the solid was scraped free from the watch glass with a scalpel and analysed by FTIR. The procedure was repeated a couple of times to remove residual $\mathrm{CN}$ material from the pigment that was subsequently analysed by PXRD. After the fabric was washed free of $\mathrm{CN}$, the warp and weft could easily be separated and analysed under the microscope and by FTIR.

\section{Optical microscopy}

The white fibres of the weft were studied under transmitted light with a Leica DMRB optical microscope with magnifications up to $200 \times$. Sample 2 was photographed with a Dino-Lite Digital Microscope FC-Z-OC2.

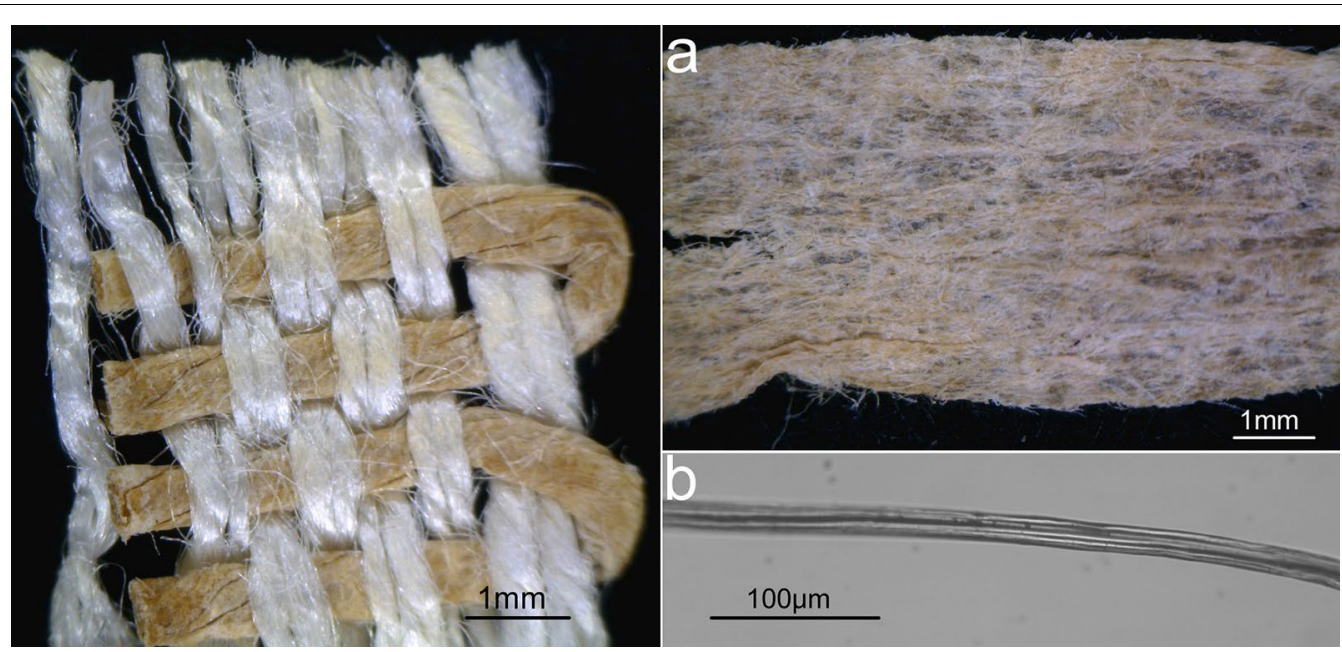

Fig. 3 Dino-Lite photo of the fabric (sample 2) after chemical removal of the coating. The sample includes the selvedge which is reinforced by a double warp. The unfolded weft consists of a paper strip of approximately $5 \mathrm{~mm}$ in width (a). In transmission microscope, the fibres of the warp show longitudinal striations characteristic of viscose rayon (b) 


\section{Centrifugation}

Centrifugation was carried out with a Savant SpeedVac Concentrator. Neither vacuum, nor heat was applied.

\section{ATR-FTIR}

Spectra were recorded on a Nicolet iS5 FTIR-spectrometer from ThermoFisher Scientific, equipped with an attenuated total reflectance (ATR) unit with a monolithic diamond crystal. Spectra were recorded in the range from 4000 to $650 \mathrm{~cm}^{-1}$ with a spectral resolution of $4 \mathrm{~cm}^{-1}$ and 60 accumulations. The spectra were compared with spectral reference data in the database of OMNIC and OMNIC SPECTRA.

\section{NMR}

NMR measurements $\left({ }^{1} \mathrm{H},{ }^{13} \mathrm{C}\left\{{ }^{1} \mathrm{H}\right\}\right.$, and ${ }^{1} \mathrm{H}-{ }^{1} \mathrm{H}$ COSY (GP)) were carried out using a $500 \mathrm{MHz}$ Bruker instrument with a cryoprobe. $\mathrm{CDCl}_{3}$ solvent signals were used for calibration $\left(\mathrm{CDCl}_{3}: 7.26\right.$ and $77.16 \mathrm{ppm}$ for ${ }^{1} \mathrm{H}$ and ${ }^{13} \mathrm{C}$, respectively). The measurements were performed at ambient temperature. Number of scans were 16 for ${ }^{1} \mathrm{H}$ and 32 for ${ }^{13} \mathrm{C}\left\{{ }^{1} \mathrm{H}\right\}$; acquisition time was $3.17 \mathrm{~s}$ for ${ }^{1} \mathrm{H}$ and $1.10 \mathrm{~s}$ for ${ }^{13} \mathrm{C}\left\{{ }^{1} \mathrm{H}\right\}$. The spectral datasets were pre-processed with Mnova NMR 8.1. Integration of the shaded areas was performed with OriginPro 2017.

\section{MALDI-MS}

MALDI MS were recorded on a Bruker Solarix XR $7 \mathrm{~T}$ ESI/MALDI-FTICR-MS instrument operating in reflectron positive ion mode. Dithranol spiked with sodium trifluoroacetate (NaTFA) was used as MALDI-matrix, and external calibration was performed with NaTFA cluster-ions from the ESI source. MALDI excitation was carried out with a Bruker SmartBeam-II $355 \mathrm{~nm}$ laser running at $15 \%$ power. Spectra were recorded at $150-4000 \mathrm{~m} / \mathrm{z}$ using small spot-size at a frequency of $200 \mathrm{~Hz} .20$ laser shots were used at each spot, with the XY-table being moved in raster mode.

\section{PXRD}

PXRD-analyses were performed with a Bruker D8 Advance diffractometer using $\mathrm{Ni}$-filtered $\mathrm{Cu}-\mathrm{K} \alpha$ radiation $(\lambda=1.54056 \AA)$ and a Lynxeye position sensitive detector in the range $2 \theta=5-70^{\circ}\left(\Delta 2 \theta=0.01^{\circ}\right)$ with a total exposure time of $8 \mathrm{~h}$. A thin layer of material was deposited directly on the $\mathrm{Si}$ monocrystal zero-background plate and measured at ambient temperature.

\section{Results and discussion}

\section{The fabric}

FTIR spectra of the warp and weft yarns of the fabric are shown in Fig. 4. Both spectra show similar

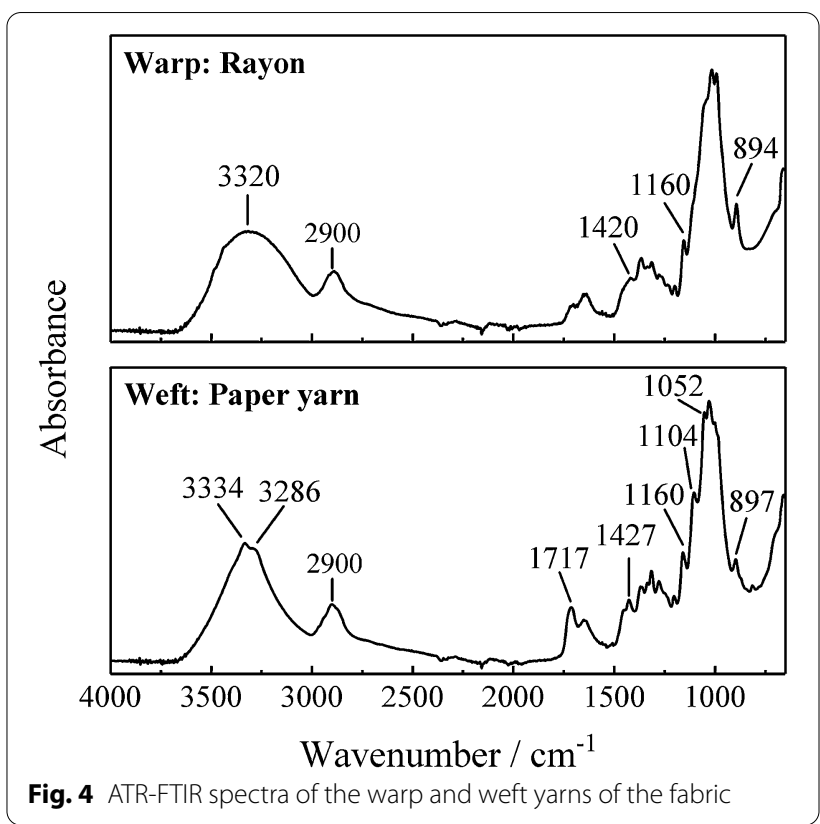

absorption bands characteristic of cellulose, e.g., a broad $\mathrm{O}-\mathrm{H}$ stretching band centred around $3320 \mathrm{~cm}^{-1}$, $\mathrm{C}-\mathrm{H}$ stretch around $2900 \mathrm{~cm}^{-1}, \mathrm{C}-\mathrm{O}-\mathrm{C}$ antisymmetric stretch around $1160 \mathrm{~cm}^{-1}$ and a strong absorption from $\mathrm{C}-\mathrm{O}$ stretch around $1030 \mathrm{~cm}^{-1}$ [6]. In the spectrum of the warp the lack of well-defined $\mathrm{C}-\mathrm{O}-\mathrm{C}$ stretching bands at $1104 \mathrm{~cm}^{-1}$ and $1052 \mathrm{~cm}^{-1}$ as well as the rather curved shape of the $\mathrm{O}-\mathrm{H}$ stretching band, is indicative of regenerated cellulose [6] and the spectrum is in accordance with an own reference of regenerated cellulose ( $c f$. Additional file 1: Fig. S4).

Regenerated cellulose fibres were either produced as filament fibres (continuous fibres) extensively used for artificial silk, or as staple fibres (fibres of finite length) used in spinning. It is likely that the yarn consists of staple fibres, that can be recognized by the relatively high number of loose fibre ends sticking out of the yarn (Fig. 3). In the German language at the time, the filament fibres usually went under the name Kunstseide (artificial silk) changing to the English term rayon after WWII, whereas Zellwolle was introduced as name for staple fibres in 1935 [7]. In this paper, the term rayon is used for both filament and staple fibres.

The most common way to make rayon was from the viscose process (see historical discussion below). Under the microscope, viscose rayon was easily recognized by the characteristic longitudinal striations caused by the irregular cross-section of the fibres [8], $c f$. Fig. 3b and Additional file 1: Fig. S5. The fibres are loosely Z-spun into a two-ply yarn with an S-twist. By opening and untwisting a sample of the weft yarn with a preparation 
needle, the material was easily identified as paper yarn as expected from the description of Hygebjerg-Hansen. The unfolded sample consisted of a brown paper strip of approximately $5 \mathrm{~mm}$ in width (Fig. 3a).

\section{The coating}

Sample 1 from the lifting coating was analysed by FTIR on both sides. No major differences were seen between the two spectra ( $c f$. Fig. 5 and Additional file 1: Fig. S6). The spectrum of the topside of sample 1 , and of the extracted and separated coating materials from sample 2, are shown in Fig. 5. In the top spectrum of Fig. 5 (topside of sample 1), characteristic bands at 1637 and $1274 \mathrm{~cm}^{-1}$ (asymmetric and symmetric $\mathrm{NO}_{2}$ stretch), $833 \mathrm{~cm}^{-1}$ (N-O stretch) $1058 \mathrm{~cm}^{-1}$ (C-O stretch), indicates the presence of cellulose nitrate $(\mathrm{CN})$ [9]. Absorption at $1714 \mathrm{~cm}^{-1}$ relates to the carbonyl band of the plasticiser, whereas strong absorption around $750 \mathrm{~cm}^{-1}$, plausibly indicates the presence of titanium dioxide white [10]. The presence of titanium dioxide was confirmed by PXRD (see below).

The FTIR-spectrum of the clear fluid plasticiser (extracted with chloroform as described in the experimental section) is shown in Fig. 5, middle spectrum. The carbonyl band at $1726 \mathrm{~cm}^{-1}$ in combination with $\mathrm{C}-\mathrm{O}$ stretching bands at 1173 and $1137 \mathrm{~cm}^{-1}$ reveals the presence of an ester, whereas relative strong absorption at $1378 \mathrm{~cm}^{-1}$ reveals a relatively high amount of methyl $\left(\mathrm{CH}_{3}\right)$ groups (symmetrical bending vibrations) [11]. The carbonyl band of the plasticiser is seen at somewhat lower wavenumbers in the spectrum of the coating, what may relate to hydrogen bonds between the carbonyl group of the plasticiser and the $\mathrm{CN}$, thereby causing a shift of the carbonyl absorption to lower wavenumbers $[12,13]$. It was not possible to identify the plasticiser with FTIR due to the lack of a reference spectrum. The plasticiser was therefore analysed further by NMR and MALDI-MS.
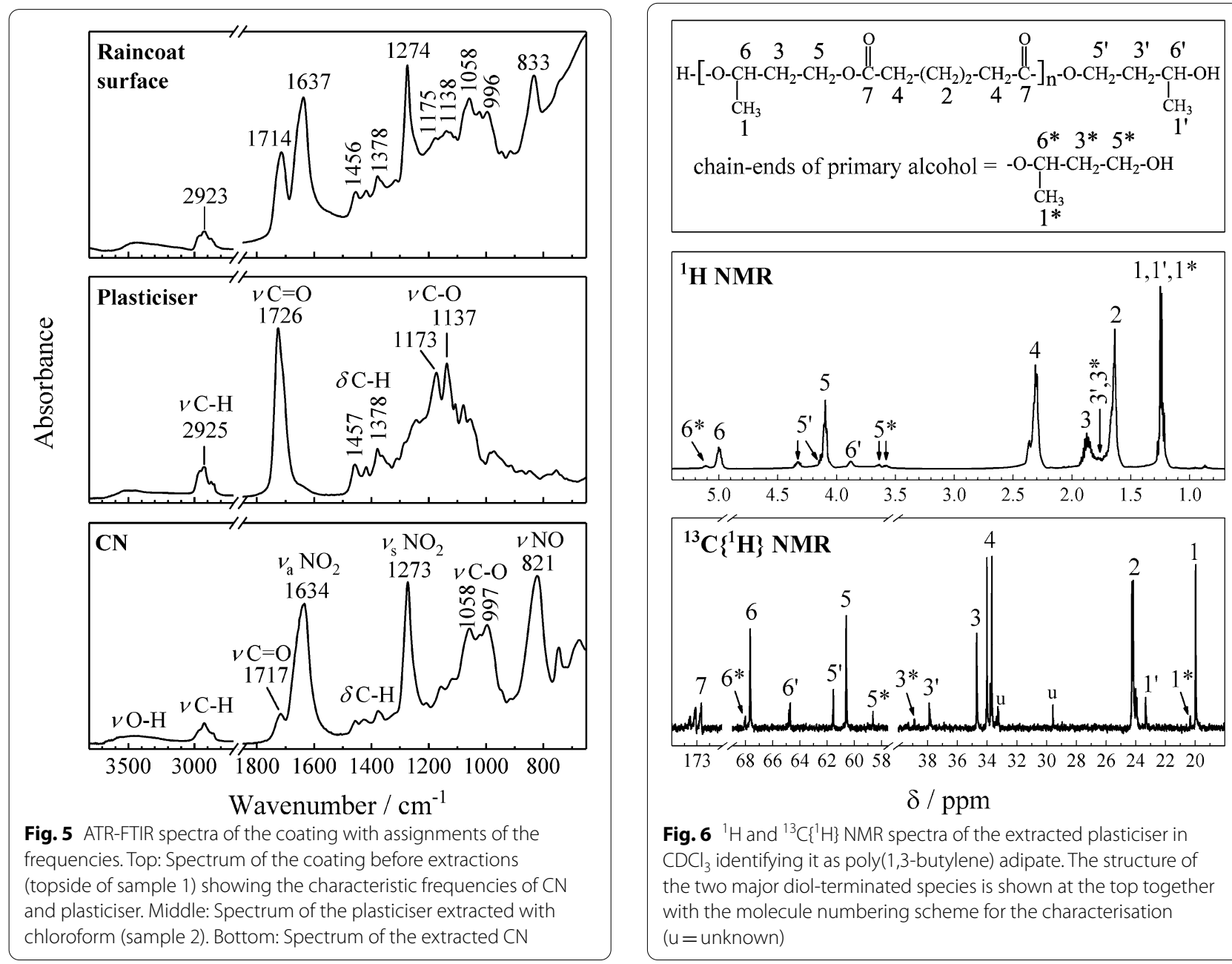

Fig. $6{ }^{1} \mathrm{H}$ and ${ }^{13} \mathrm{C}\left\{{ }^{1} \mathrm{H}\right\}$ NMR spectra of the extracted plasticiser in $\mathrm{CDCl}_{3}$ identifying it as poly(1,3-butylene) adipate. The structure of the two major diol-terminated species is shown at the top together with the molecule numbering scheme for the characterisation $(u=$ unknown $)$ 
The ${ }^{1} \mathrm{H}$ and ${ }^{13} \mathrm{C}\left\{{ }^{1} \mathrm{H}\right\}$ NMR spectra of the extracted plasticiser in $\mathrm{CDCl}_{3}$ are shown in Fig. 6, together with a drawing of the structure of the two major diol-terminated species i.e., primary and secondary alcohol, and the molecule numbering scheme used for the characterisation. Both NMR spectra are in full accordance with the thorough NMR spectrometric analysis $[14,15]$ of the commercial plasticiser Reoplex ${ }^{\circledR} 346$ from Ciba-Geigy, which thereby identify the plasticiser as poly(1,3-butylene) adipate. Integration of the areas of the hydrogen atoms neighbouring the primary alcohol in the in-chain esterified primary alcohol (5), and of its two possible monoesterified end-groups i.e. (5') from the primary alcohol esterification, and $\left(5^{*}\right)$ from the secondary alcohol esterification are shown in Fig. 7. The low ratio of $c .3$ indicates that the diol-terminated oligomers are dominant species, and that the poly(1,3-butylene) adipate oligomers are of relatively short length. Also given in Fig. 7 is the ratio between the primary alcohol esterification end-group, and the secondary alcohol esterification end-group based on $\left(5^{\prime}\right)$ and $\left(5^{*}\right)$. As can be seen from the ratio of 2.8 , the amount of free secondary alcohol in the chain-ends is greater than primary due to higher esterification reactivity of the primary alcohol.

In order to determine the oligomer chain length of the plasticiser MALDI-MS was performed as shown in Fig. 8 with insert of enlarged area of 1000 to $1500 \mathrm{~m} / z$ units. Interpretation of the oligomer repeat units (n) is shown in Fig. 9, where drawings of the structural assignments based on poly(1,3-butylene) adipate and molecular weights with addition of sodium ion $\left(\mathrm{M}+\mathrm{Na}^{+}\right)$are given.

As seen from the MS spectrum Fig. 8 and Fig. 9, the major number of oligomers are present with $n=4-9$. The low value polymerisation, and hence low average

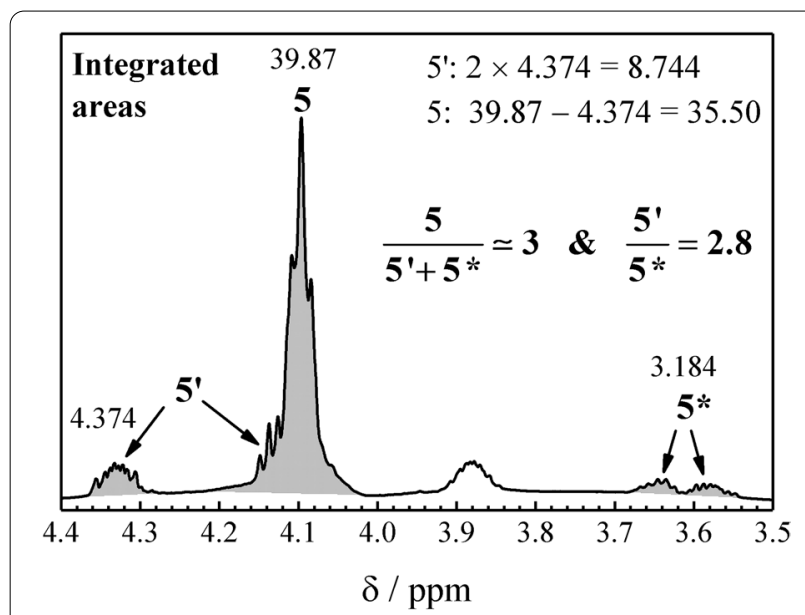

Fig. 7 Ratio of the integrated areas of the in-chain esterified primary alcohol (5) and its mono-esterified end-groups (5'and $5^{*}$ )

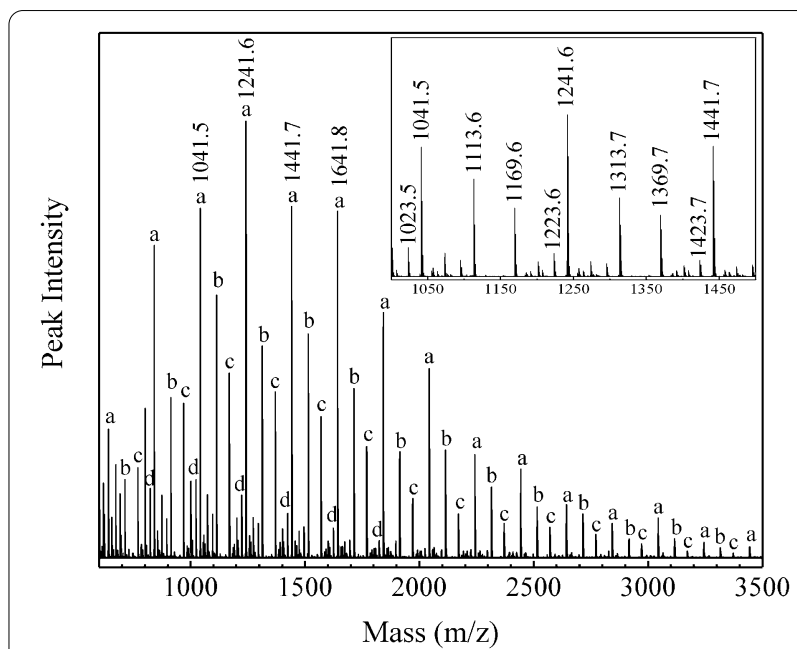

Fig. 8 MALDI-MS spectrum of the plasticiser with insert of enlarged area from 1000 to $1500 \mathrm{~m} / \mathrm{z}$ units. Structural assignments of the ion peaks, and the oligomer repeat units (n), are seen in Fig. 9

molecular weight, is in accordance with the investigation of Reoplex ${ }^{\circledR} 346$ which was published in 1991 and 2000, respectively $[14,15]$. It is, however, interesting that CibaGeigy first announced the presence of Reoplex ${ }^{\circledR} 346$ to the market in 1986 [16] but analysis of WWII polymeric materials revealed the presence of this type of plasticiser much earlier.

\section{Pigment}

The PXRD pattern of the titanium white pigment is shown in Fig. 10 and identifies it as $\mathrm{TiO}_{2}$ of the anatase form. Titanium white pigments, which have been produced on a commercial scale since 1918, were valued in particular because of their bright colour, opacity and non-toxic character [10]. Most notable of the finding, is the lack of a substrate or filler like barium sulphate or calcium sulphate, which was typically always part of the early titanium white pigments. The pure form of anatase was developed in the early 1920s, but the price was far higher than that of the composites [17], with the pure form first gaining importance as a pigment in the 1940s [18].

\section{Historic discussion}

The textile

Of the two yarns identified in the raincoat, rayon staple fibres and paper, the former was of greatest importance in the textile industry for clothing during WWII. At the time, the most common way to make rayon was by the viscose method, whereby a refined wood pulp was commonly used as raw material. By treating the wood pulp with chemicals, it was converted to a xanthate derivative 


\begin{tabular}{|c|c|}
\hline Structure $(M)$ and species notation a - d & $(\mathrm{M}+\mathrm{Na})^{+}$ \\
\hline $\mathrm{H}-\left[-\mathrm{O}-\prod_{\mathrm{CH}_{3}}^{\mathrm{CH}}-\mathrm{CH}_{2}-\mathrm{CH}_{2}-\mathrm{O}-\stackrel{\mathrm{C}}{\|}-\left(\mathrm{CH}_{2}\right)_{4}-\mathrm{C}-\right]_{\mathrm{n}}-\mathrm{OH}$ & $\begin{array}{l}1041.5(\mathrm{n}=5) \\
1241.6(\mathrm{n}=6) \\
1441.7(\mathrm{n}=7) \\
1641.8(\mathrm{n}=8)\end{array}$ \\
\hline 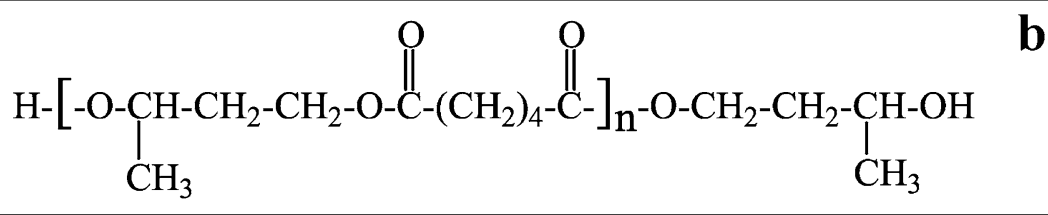 & $\begin{array}{l}1113.6(\mathrm{n}=5) \\
1313.7(\mathrm{n}=6) \\
1513.8(\mathrm{n}=7) \\
1713.9(\mathrm{n}=8)\end{array}$ \\
\hline 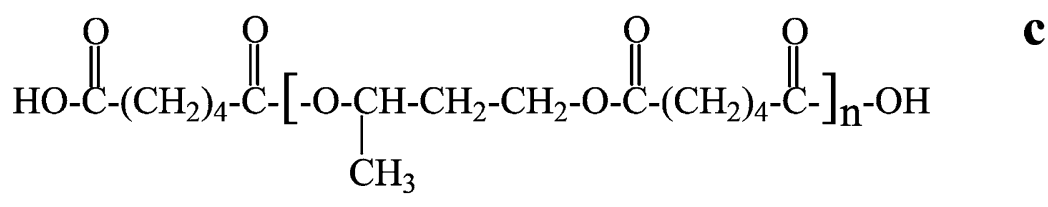 & $\begin{array}{l}1169.6(\mathrm{n}=5) \\
1369.7(\mathrm{n}=6) \\
1569.8(\mathrm{n}=7) \\
1769.9(\mathrm{n}=8)\end{array}$ \\
\hline$-\left[-\prod_{\mathrm{CH}_{3}}^{\mathrm{C}}-\mathrm{CH}_{2}-\mathrm{CH}_{2}-\mathrm{O}-\mathrm{C}-\left(\mathrm{CH}_{2}\right)_{4}-\mathrm{C}-\right]_{\mathrm{n}}$ & $\begin{array}{l}1023.5(\mathrm{n}=5) \\
1223.6(\mathrm{n}=6) \\
1423.7(\mathrm{n}=7) \\
1623.8(\mathrm{n}=8)\end{array}$ \\
\hline
\end{tabular}

Fig. 9 Structural assignments of ion peaks shown in Fig. 8 and the molar masses of the oligomer repeat units (n)

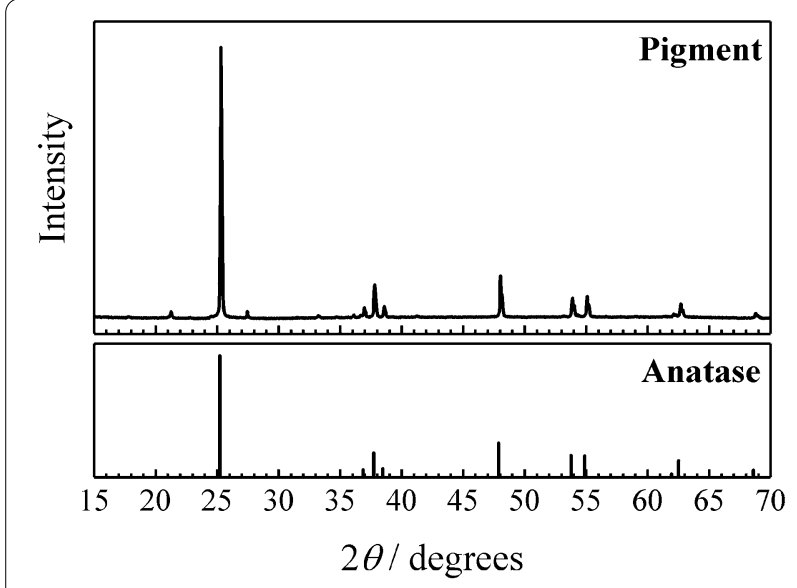

Fig. 10 PXRD of the pigment and anatase

and solubilised to a viscous liquid (the viscose). Extruded through spinnerets into a coagulation bath and rinsed free of chemicals, the viscose was converted into white cellulosic fibres that were either wound up on spools as rayon filament fibres (used for artificial silk) or cut in discrete lengths and further treated to spin well (the rayon staple fibres) $[7,19]$.

The production of rayon staple fibres in Germany in the 1930s and during WWII was strongly influenced by the Nazi autarkic politics. Autarky meant as far as possible to be self-sufficient in raw materials and not to depend on import. The textile industry, with its high level of imported raw materials such as cotton and wool, was a particularly challenging sector in this respect. Rayon staple fibres, able to be produced from domestic wood and chemicals readily available, became extremely attractive $[20,21]$.

The use of rayon staple fibres in Denmark was quite modest until the German occupation in 1940. With one stroke, Denmark was cut off from its cotton suppliers, and the rayon staple fibres soon became its most important substitute [1]. Like staple fibres, the use of paper yarn strongly increased during the occupation period in Denmark to replace the previously imported fibres; jute and hemp [1]. Paper yarn was strong, stiff and inflexible, and often impregnated to resist water. It was used for ropes, twine, baling twine, sacks and as a component in webbing $[22,23]$. In contrast to rayon staple fibres, the stiffness of the paper yarn did not make it suitable as a substitute fibre in clothing. Its use in clothing during WWI, particularly in Germany, was due to the lack of more appropriate fibres $[23,24]$. The finding in the raincoat would indicate that rayon staple fibres were in short supply, something which is known to have happened during the time from which the raincoat dates. Thus, in 1943, Germany experienced a critical shortage of spinning fibres for the first 
time since the beginning of the war [25]. Moreover, major deliveries of rayon staple fibres to Denmark from Italy ceased after the Fascist regime collapsed in July the same year [1]. Because of the shortage of rayon staple fibres, paper yarn was increasingly used as substitute [1]. Paper was abundantly available in the end of 1943 and did not become scarce before the summer/autumn of 1944, when Sweden reduced and eventually ceased export of paper to Denmark. The scarcity of both paper yarn and rayon staple fibres in 1944 was countered with an increased production of domestic flax $[1,26]$.

\section{The coating}

The finding of the $\mathrm{CN}$-lacquer as coating material falls within a time when $\mathrm{CN}$-lacquer was one of the most important lacquers on the market.

The breakthrough of $\mathrm{CN}$ lacquer for large industrial use happened in the years after WWI and was mainly driven by improvements in the film forming properties, as well as greater availability of proper solvents [27, 28]. The fast drying time made the lacquer particularly attractive for industrial use, and it became indispensable in the fast growing automobile industry [29]. Moreover, since the 1880s, CN lacquer, usually plasticised with resinous oil, played a major role in the production of faux (artificial) leather, for instance in carriage coverings, bookbinding and upholstery [30,31]. Of particular interest when looking into the use of CN-lacquer during WWII, was the introduction of wood pulp as a raw material in the late 1930s [27]. As described earlier, the use of refined wood pulp already played a major role in the production of rayon staple fibres in the textile industry. But it was not until late into the 1930s that the industry managed to produce a wood pulp pure enough to replace cotton as raw material for CN-lacquer [27]. With wood pulp as a raw material, the lacquer production not only survived the cut off of cotton during wartime, but its use expanded to areas where it had not been traditionally used [27]. This also applies to the raincoat, where the water resistance of the $\mathrm{CN}$-lacquer, its traditional use within the faux leather production and more importantly, its availability during the occupation, made it a logical choice as a coating material in a time where the most common material for this purpose, rubber, was not available.

\section{The plasticiser}

Of all the findings pertaining to the raincoat, the plasticiser poly(1,3-butylene) adipate is the most surprising. The authors found no mention of poly(1,3-butylene) adipate in the plasticiser literature of the time, nor in the patent literature. It is not until 1986, that the Swiss firm Ciba-Geigy introduces poly(1,3-butylene) adipate as a plasticiser under the tradename Reoplex ${ }^{\circledR} 346$ for use within PVC cling films, where it is appreciated for its low volatility preventing its migration into food $[15,16]$. It is likely that poly(1,3-butylene) adipate existed in the 1940s under one of the several commercial names that did not disclose the composition of their content [32]. Probably it had been developed for PVC in the first place, exactly like Reoplex more than 40 years later. Perhaps the traditional plasticiser used for flexible $\mathrm{CN}$-coatings, resinous oil [33], was in short supply, like other overseas products.

The 1940s saw a rapid development of plasticisers, primarily due to their indispensability for many of the new synthetic polymers that were on the market at the time, in particular PVC. Linear polyester plasticisers (noncyclic condensation products of dibasic acids and dihydric alcohols), were introduced in 1942 by Rohm \& Hass Laboratories in Philadelphia, as excellent non-volatile plasticisers for PVC and PVC-acetate [34, 35]. The finding of this type of plasticiser in the raincoat is thus rather surprising and indicates that Europe was not behind the USA when it came to their development. It is remarkable, however, that no sources on their early production in Europe seem to be available, and the finding in the raincoat may be the earliest of its kind reported on European ground.

Though no European firm can be connected directly with the plasticiser, there is good reason to believe it was produced in Germany and probably by IG Farben AG, which was the leading European firm when it came to polymer science, and the largest chemical company in Europe.

IG Farben, the result of a merger in 1925 of leading chemical companies, including Badische Anilin- and Soda-Fabrik (BASF), Bayer and Höchst, began focusing on polymers early on [36, 37], and was one of the first companies worldwide to produce PVC on large scale in $1937[38,39]$.

It is, however, the production of synthetic rubber or Buna, which may connect the plasticiser to IG Farben. Buna (acronym for butadiene and Natrium (German for sodium, the catalyst for the synthesis)) was developed by IG Farben chemists in the late 1920s and was an improvement of earlier synthetic rubber products. In general, the term Buna covers a copolymer of butadiene and styrene (Buna-S). 1,3-butanediol, the one monomer in the plasticiser, was an intermediate in the four-step process (Vierstufen Verfahren) used by IG Farben to obtain butadiene from acetylene [40-42]:

$$
\begin{aligned}
& \mathrm{CH} \equiv \mathrm{CH}+\mathrm{H}_{2} \mathrm{O} \rightarrow \mathrm{CH}_{3} \mathrm{CHO} \\
& 2 \mathrm{CH}_{3} \mathrm{CHO} \rightarrow \mathrm{CH}_{3} \mathrm{CHOCH}_{2} \mathrm{CHO}
\end{aligned}
$$




\section{$\mathrm{CH}_{3} \mathrm{CHOCH}_{2} \mathrm{CHO}+\mathrm{H}_{2} \rightarrow \mathrm{CH}_{3} \mathrm{CHOHCH}_{2} \mathrm{CH}_{2} \mathrm{OH}$}

$\mathrm{CH}_{3} \mathrm{CHOHCH}_{2} \mathrm{CH}_{2} \mathrm{OH} \rightarrow \mathrm{CH}_{2}=\mathrm{CHCH}=\mathrm{CH}_{2}+2 \mathrm{H}_{2} \mathrm{O}$

As seen above, 1,3-butanediol is the product of the hydrogen reduction of aldol in the third step.

The high cost of the four-step process made Buna noncompetitive with natural rubber, and large-scale production was only realised as part of the Nazi autarkic politics of the 1930s, culminating with the four-year plan of 1936 [43]. Buna was particularly important for the tires of the fast-growing automobile industry and moreover, indispensable for the clandestine rearmament $[40,44]$. The first Buna factories for large scale production were erected in Schkopau (1939) and Hüls in Marl (1940) [40].

In 1937 IG chemist Walter Reppe developed the more profitable three-step process to produce butadiene:

$$
\begin{aligned}
& \mathrm{CH} \equiv \mathrm{CH}+2 \mathrm{HCHO} \rightarrow \mathrm{HOCH}_{2} \mathrm{C} \equiv \mathrm{CCH}_{2} \mathrm{OH} \\
& \mathrm{HOCH}_{2} \mathrm{C} \equiv \mathrm{CCH}_{2} \mathrm{OH}+2 \mathrm{H}_{2} \rightarrow \mathrm{HOCH}_{2} \mathrm{CH}_{2} \mathrm{CH}_{2} \mathrm{CH}_{2} \mathrm{OH}
\end{aligned}
$$

Of particular interest, is the finding of poly(1,3-butylene) adipate as a plasticiser in the cellulose nitrate lacquer coating. The first known description and marketing of this plasticiser is from 1986 where the Swiss firm CibaGeigy introduced poly(1,3-butylene) adipate as a plasticiser for PVC cling films under the tradename Reoplex ${ }^{\circledR}$ 346 . However, this study suggests that the plasticiser was developed much earlier in Germany by IG Farben, likely due to the relation of 1,3-butanediol in its Buna production. The finding is also interesting in other aspects as it shows that intermediate chemical products of the war industry were re-directed into civilian end-products.

It is likely that many chemical advancements and experiments that took place up to, and during WWII may have been forgotten in the chaotic final years of the war. Objects left over from that time may be the only witnesses of this progress, hiding secrets of the chemical industry's search for new synthetic materials. Indeed, the successful revelation of the polymeric plasticiser by MALDI-MS and NMR gives new insights into the advancements of the chemical industry during WWII.

$$
\mathrm{HOCH}_{2} \mathrm{CH}_{2} \mathrm{CH}_{2} \mathrm{CH}_{2} \mathrm{OH} \rightarrow-\mathrm{H}_{2} \mathrm{O} \quad \mathrm{C}_{4} \mathrm{H}_{8} \mathrm{O} \rightarrow^{-\mathrm{H}_{2} \mathrm{O}} \mathrm{CH}_{2}=\mathrm{CHCH}=\mathrm{CH}_{2}
$$

As seen above, In the Reppe process or three-step process, 1,3-butanediol was no longer an intermediate product. The three-step process was introduced in the third Buna factory, erected in 1941-1943 at Ludwigshafen. Buna was, however, still produced from the four-step process in the old factories while conversion to the threestep process was not technically possible [40].

The finding of 1,3-butanediol as a monomer in a plasticiser used for a $\mathrm{CN}$-lacquer of a raincoat may seem strange considering how important Buna was for military uses. However, the Buna factories were also involved in the production of polymers and plasticisers $[40,45]$. This fact may plausibly explain why an important intermediate product of the Buna industry ended up in a polymeric plasticiser probably developed for the PVC industry.

\section{Conclusion}

This study provides interesting knowledge on the availability of raw materials in Denmark during the German occupation, when many overseas materials like wool, cotton and rubber were in scarce supply. The major importance of wood pulp in the substitution industry is reflected in the fact that it was used as basis for all main materials of the raincoat; the paper and rayon staple fibre yarn of the textile, as well as the CN-lacquer of the coating. In particular, the finding of paper yarn supports the dating of the raincoat to 1943, a year in which this material was increasingly used as substitute.
Analyses of other objects from the period may throw further light on this important chapter of material history.

\section{Supplementary Information}

The online version contains supplementary material available at https://doi. org/10.1186/s40494-021-00572-7.

Additional file 1. Additional figures.

\section{Acknowledgements}

The authors thank museum inspector Lola Wöhlk Hansen from Glud Museum. Moreover, Thomas Cox and Bodil Klarskov Sylvester for proofreading the text and their valuable comments.

\section{Authors' contributions}

All authors contributed to data interpretation and to finalising the manuscript. All authors read and approved the final manuscript.

\section{Funding}

Not applicable.

\section{Availability of data and materials}

The datasets used and/or analysed during the current study are available from the corresponding author on reasonable request.

\section{Declarations}

\section{Competing interests}

The authors declare that they have no competing interests.

\section{Author details}

${ }^{1}$ Conservation Centre Vejle, Maribovej 10, 7100 Vejle, Denmark. ${ }^{2}$ Department of Chemistry, University of Copenhagen, Universitetsparken 5, 2100 Copenhagen $\varnothing$, Denmark. 
Received: 30 May 2021 Accepted: 8 August 2021

Published online: 15 September 2021

\section{References}

1. Jensen S. Levevilkår under besættelsen: Træk af den økonomiske og sociale udvikling i Danmark under den tyske besættelse 1940-1945. København: Gyldendal; 1971.

2. Hygebjerg-Hansen AJ. En gammel Vejle-forretning. In: Hygebjerg-Hansen AJ, editor. Vejle Textilhandlerforening - igennem 100 år. Vejle: Byhistorisk Forlag; 1997. p. 57-60

3. Jensen HA. Regnbeklædning. In: Sterm P, editor. Textilbogen. København: Westermanns Forlag; 1946. p. 408-15.

4. Kjeldbæk E. Det er koldt. In: Lundbak H, editor. Spærretid. Hverdag under besættelsen. København: Nationalmuseet; 2005. p. 56-61.

5. Shashoua Y, Skals I. Development of a conservation strategy for a collection of waterproofed military uniforms. Conserv. 2004;28:57-65.

6. Comnea-Stancu IR, Wieland K, Ramer G, Schwaighofer A, Lendl B. On the identification of rayon/viscose as a major fraction of microplastics in the marine environment: discrimination between natural and manmade cellulosic fibres using Fourier transform infrared spectroscopy. Appl Spectrosc. 2017;71:939-50.

7. Götze K. Chemiefasern nach dem Viskoseverfahren. 2nd ed. Berlin: Springer-Verlag; 1951.

8. Schuster K. Die Rohstoffe für die Textilindustrie. Stuttgart: KonradinVerlag; 1953.

9. Mitchell G, France F, Nordon A, Tang PL, Gibson LT. Assessment of historical polymers using attenuated total reflectance-Fourier transform infrared spectroscopy with principal component analysis. Herit Sci. 2013;1:28.

10. Laver M. Titanium dioxide whites. In: FitzHugh EW, editor. Artists' pigments. A handbook of their history and characteristics. London: Archetype Publications; 1997. p. 295-355.

11. Bellamy LJ. The infra-red spectra of complex molecules. 3rd ed. London: Chapman and Hall; 1975.

12. Jutier JJ, Lemieux E, Prud'Homme RE. Miscibility of polyester/nitrocellulose blends: a DSC and FTIR study. J Polym Sci Part B: Polym Phys. 1988;26:1313-29.

13. Nunes S, Ramacciotti F, Neves A, Angelin EM, Ramos AM, Roldão É, Wallaszkovits N, Armijo AA, Melo MJ. A diagnostic tool for assessing the conservation condition of cellulose nitrate and acetate in heritage collections: quantifying the degree of substitution by infrared spectroscopy. Herit Sci. 2020;8:1-14

14. Castle L, Mercer AJ, Gilbert J. Migration from plasticized films into foods. 5. Identification of individual species in a polymeric plasticizer and their migration into foods. Food Addit Contam. 1991:8:565-76.

15. Oriol-Hemmerlin C, Pham Q. Poly 1, 3-butylene adipate Reoplex ${ }^{\circledR}$ as high molecular weight plasticizer for PVC-based cling films-microstructure and number-average molecular weight studied by $1 \mathrm{H}$ and $13 \mathrm{C} \mathrm{NMR}$. Polym. 2000:41:4401-7.

16. Wilson AS. Plasticisers: Selection, applications and implications. Shawbury: Rapra Technology Ltd; 1996

17. Wilson SP. Pyroxylin enamels and lacquers. Their raw materials, manufac ture and application. 2nd ed. New York: D. Van Nostrand Company, Inc; 1929.

18. Lauridsen CB, Sanyova J, Simonsen KP. Analytical study of modern paint layers on metal knight shields: The use and effect of Titanium white. Spectrochim Acta A Mol Biomol Spectrosc. 2014;124:638-45.

19. Bauer R. Zellwolle siegt. Leipzig: Wilhelm Goldmann Verlag; 1941.

20. Dominik H. Vistra, das weiße Gold Deutschlands: Die Geschichte einer weltbewegenden Erfindung. Leipzig: Koehler \& Amelang; 1936.

21. Höschle G. Die deutsche Textilindustrie zwischen 1933 und 1939: Staatsinterventionismus und ökonomische Rationalität. Stuttgart: Franz Steiner Verlag; 2004

22. Sterm P. Textilbogen. Haandbog i textil varekundskab. København: Westermanns forlag; 1946. p. 1
23. Drexler P: Papiergarnindustrie und Kriegswirtschaft. Würzburg: Gebrüder Memminger; 1919

24 Arndt P. Alte und neue Faserstoffe 2nd ed Berlin: Dietrich Reimer 1918.

25. Scherner J. The beginnings of Nazi autarky policy: The 'National Pulp Programme'and the origin of regional staple fibre plants. Econ Hist Rev. 2008;61:867-95.

26. Statistics of Industrial Production 1944. Copenhagen: the Statistical Department.

27. Kraus A. Handbuch der Nitrocelluloselacke. Teil 2. Nitrocelluloselacke. Berlin-Wilmersdorf: Wilhelm Pansegrau Verlag; 1952.

28. Doolittle AK. The technology of solvents and plasticizers. New York: Wiley; 1954.

29. Standeven H. House paints, 1900-1960: history and use. Los Angeles: Getty Publications; 2011.

30. Worden EC. Nitrocellulose industry: A compendium of the history, chemistry, manufacture, commercial application and analysis of nitrates, acetates and xanthates of cellulose as applied to the peaceful arts, with a chapter on gun cotton, smokeless powder and explosive cellulose nitrates. New York: D. Van Nostrand Company; 1911;2

31. Münzinger WM. Kunstlederhandbuch. Herstellung und Eigenschaften von Kunstleder und lederähnlichen Werkstoffen. Berlin-Wilmersdorf: Wilhelm Pansegrau Verlag; 1950.

32. Gnamm H. Die Lösungsmittel und Weichmachungsmittel. 5th ed. Stuttgart: Wissenschaftliche Verlagsgesellschaft M.B.H; 1946.

33. Kraus A. Handbuch der Nitrocelluloselacke. Teil 3. Weichmachungsmittel. Berlin-Wilmersdorf: Wilhelm Pansegrau Verlag; 1961.

34. Koroly JE, Beavers EM. Polymeric plasticizers-preparation and characterization of a series of terminated polyesters. Ind Eng Chem. 1953:45:1060-3.

35. B. H: Neue Kunststoffe/ Kunststoffchemie/ Kunststoffphysik. Polymere Weichmacher. Kunstst. 1954:44:257.

36. ter Meer F. Die IG Farben Industrie Aktiengesellschaft: Ihre Entstehung, Entwicklung und Bedeutung. Düsseldorf: Econ-Verlag GMBH; 1953.

37. Reinhardt C. Basic research in industry: Two case studies at IG Farbenindustrie AG in the 1920's and 1930's. In: Morris PJT, editor. Determinants in the Evolution of the European Chemical Industry, 1900-1939. . Dordrecht: Kluwer Academic Publishers; 1998. p. 67-88.

38. Kaufmann M. The first century of plastics - celluloid and its sequel. London: Chameleon Press Ltd.; 1963.

39. Braun D. PVC — origin, growth, and future. J Vinyl Add Tech. 2001;7:168-76.

40. Morris PJ. Ambros, Reppe, and the emergence of heavy organic chemicals in Germany, 1925-1945. In: Travis AS, Schröter HG, Homburg E, Morris PJT, editors. Determinants in the evolution of the European Chemical Industry, 1900-1939. Dordrecht: Kluwer Academic Publishers; 1998. p. 89-122.

41. Weitz HM, Hartig J. Butadien. In: Bartholomé E, Biekert E, Hellmann H, editors. Ullmanns Encyklopädie der technischen Chemie. Weinheim: Verlag Chemie; 1975. p. 1-18.

42. Reppe W. Neue Entwicklungen auf dem Gebiete der Chemie des Acetylens und Kohlenoxyds. Berlin: Springer-Verlag; 1949.

43. Petzina D. Autarkiepolitik im Dritten Reich. Der nationalsozialistische Vierjahresplan. Stuttgart: Deutsche Verlags-Anstalt; 1968.

44. Treue W. Hitlers Denkschrift zum Vierjahresplan 1936. Vierteljahrsh Zeitgesch. 1955:3:184-203.

45. Wünsch Fl. Das Werk Hüls: Geschichte der Chemische Werke Hüls AG in Marl von 1938 bis 1949. Tr Z Firmengescht Unternehmerbiogr. $1964 \cdot 9 \cdot 70-9$

\section{Publisher's Note}

Springer Nature remains neutral with regard to jurisdictional claims in published maps and institutional affiliations. 